\title{
Patient with stroke: hospital discharge planning, functionality and quality of life
}

Doente com acidente vascular cerebral: planeamento de alta, funcionalidade e qualidade de vida

Paciente con accidente cerebrovascular: planificación del alta, funcionalidad y calidad de vida

\section{Henrique José Mendes Nunes', Paulo Joaquim Pina Queirós'}

'Escola Superior de Enfermagem de Coimbra. Coimbra, Portugal.

How to cite this article:

Nunes HJM, Queirós PJP. Patient with stroke: hospital discharge planning, functionality and quality of life. Rev Bras Enferm [Internet]. 2017;70(2):415-23. DOI: http://dx.doi.org/10.1590/0034-7167-2016-0166

\author{
Submission: 05-16-2016 Approval: 11-20-2016
}

\begin{abstract}
Stroke still causes high levels of human inability and suffering, and it is one of the main causes of death in developed countries, including Portugal. Objective: analyze the strategies of hospital discharge planning for these patients, increasing the knowledge related to hospitalhome transition, discharge planning processes and the main impact on the quality of life and functionality. Method: integrative literature review using the PICOD criteria, with database research. Results: 19 articles were obtained, using several approaches and contexts. For quality of life, the factors related to the patient satisfaction with care and the psychoemotional aspects linked with functionality are the most significant. Conclusion: during the hospitalization period, a careful hospital discharge planning and comprehensive care to patients and caregivers - in particular the functional and psychoemotional aspects - tend to have an impact on the quality of life of patients.

Descriptors: Stroke; Quality of Life; Patient Discharge; Rehabilitation; Nursing.
\end{abstract}

\section{RESUMO}

O acidente vascular cerebral ainda origina elevados níveis de incapacidade e sofrimento humano, sendo das primeiras causas de morte nos países desenvolvidos, incluindo em Portugal. Objetivo: analisar as estratégias adotadas no planeamento da alta destes doentes, aprofundando o conhecimento inerente à transição hospital-domicílio, aos processos de preparação de alta assim como às principais repercussões na qualidade de vida e funcionalidade. Método: revisão integrativa de literatura, pelos critérios orientadores PICOD, com pesquisa em base de dados. Resultados: obtidos 19 artigos, com diversas abordagens e contextos. Para a qualidade de vida importa a satisfação com os cuidados recebidos e a consideração dos aspetos psico-emocionais, ligados à funcionalidade. Conclusão: no tempo de internamento, o planeamento cuidado da alta, o cuidado abrangente a doentes e cuidadores - nomeadamente aspectos funcionais e psico-emocionais - tendem a ter impacto na qualidade de vida dos doentes.

Descritores: Acidente Vascular Cerebral; Qualidade de Vida; Alta do Paciente; Reabilitação; Enfermagem.

\section{RESUMEN}

El accidente cerebrovascular todavía lleva a elevados niveles de incapacidad y sufrimiento humano, y es una de las primeras causas de muerte en los países desarrollados, incluido Portugal. Objetivo: analizar las estrategias adoptadas en la planificación del alta de estos pacientes profundizando en el conocimiento inherente a la transición del hospital al domicilio, a los procesos de preparación del alta, así como a las principales repercusiones en la calidad de vida y la funcionalidad. Método: revisión integradora de la literatura por los criterios orientadores PICOD con una búsqueda en bases de datos. Resultados: se obtuvieron 19 artículos con diversos enfoques y contextos. Para la calidad de vida importa la satisfacción con los cuidados recibidos y la consideración de los aspectos psicoemocionales ligados a la funcionalidad. Conclusión: en el tiempo de internamiento, la planificación cuidada del alta, el cuidado integral a los pacientes y cuidadores -en particular los aspectos funcionales y psicoemocionales- tienden a tener un impacto en la calidad de vida de los pacientes. Descriptores: Accidente Cerebrovascular; Calidad de Vida; Alta del Paciente; Rehabilitación; Enfermería. 


\section{INTRODUCTION}

An increase in the average life expectancy of the population worldwide has been followed by an increased incidence of chronic diseases, reaching statistical dimensions that force specific actions by health professionals, in particular nurses. To understand this, it is important to learn the issues of hospital discharge planning and their impact on the functionality and quality of life (QoL) of patients, contributing to better care.

In the sphere of an ongoing study on ischemic stroke - also called cerebrovascular accident (CVA) - and converging concepts such as of functionality, QoL, length of hospital stay and hospital discharge processes/post-hospital referral (among others), we wanted to frame what the literature has presented and emphasized in recent years in this field into a methodologically organized and focused study. Aware of its social impacts on mortality ${ }^{(1)}$ and morbidity indicators, levels of inability and suffering typically caused by stroke, the negative impact on the quality of life of patients and their families ${ }^{(2)}$, and the difficult control of several risk factors ${ }^{(3-4)}$, we have conducted an integrative literature review to clarify the study question: "Are the impacts on QoL and functionality of patients after a stroke related to length of stay and hospital discharge planning?".

The resulting studies were analyzed to provide a response to the concerns above, based on the study title and question. The study conducted observed the framework of the Meleis' Theory of Transitions ${ }^{(5)}$ and considered a nonlinear view of the complex processes addressed by Morin ${ }^{(6)}$.
The general objective of this study was to increase the knowledge on the theme, particularly by means of analyzing the concerns related to the hospital-home transition, focused on the hospital discharge and the clarification of impacts on QoL, functionality and cognitive-emotional aspects of patients.

\section{METHOD}

Regarding the methodology, several study strategies or approaches (arrangements of key words) were used in the integrative literature review. In the beginning of the fourth quarter of 2014, we analyzed the scientific literature published in the search engine EBSCO, checking the main databases (MEDLINE with Full Text, $\mathrm{Cl}$ NAHL Plus with Full Text, MedicLatina and Psychology and Behavioral Sciences Collection), and we selected the studies that generally respected some inclusion criteria, although without an inflexible limitation or condition that could result from an elaborated strategy; however, following a consensual methodology that could fulfill the needs of participants and be used in the interventions, comparisons, results and design of the studies [PICOD]. The criteria are presented in Chart 1, not considering the lines of comparisons [C].

The exclusion criteria considered were studies not conducted in the period defined for each approach, studies that did not address impacts or analysis vectors requested, studies that did not address the specific scope of the underlying pathology, studies that did not have their full text available or that had not been written in Portuguese, English or Spanish.

Exceptions were admitted, as indicated in Chart 2.

Chart 1 - Criteria for inclusion of studies in the integrative review

\begin{tabular}{|l|l|}
\hline \multicolumn{1}{|c|}{ PI[C]OD } & \multicolumn{1}{c|}{ Description } \\
\hline Participants & Patients, services and care processes, caregivers of patients with CVA (acute brain injury and consequences). \\
\hline Interventions & $\begin{array}{l}\text { Approaches and dimensions like functionality, quality of life, depressive symptoms, hospitalization processes and length } \\
\text { of stay, hospital discharge and discharge planning, caregivers, rehabilitation and its mechanisms. }\end{array}$ \\
\hline $\begin{array}{l}\text { Results of the } \\
\text { investigation }\end{array}$ & $\begin{array}{l}\text { Evidence and relationships among the variables, regarding the strategies implemented and presented as the results or } \\
\text { outcomes. }\end{array}$ \\
\hline Design of the study & It did not constitute an inclusion/exclusion criterion. \\
\hline
\end{tabular}

Note: $P I[C] O D=$ Participants, Intervention, [Comparisons], Results, Design; CVA = cerebrovascular accident.

Chart 2 - Strategies $\left(S_{1}\right.$ to $\left.S_{7}\right)$ used in the search for studies, regarding the key words used, the study fields specified, the period defined, options of text availability, number of resulting articles and final number of articles (selected)

\begin{tabular}{|l|l|c|c|c|c|c|}
\hline $\mathbf{S}$ & Key words & Fields specified & Period & Full text? & RES & RES/ Final \\
\hline $\mathrm{S}_{1}$ & stroke/quality of life/discharge planning & Abst/Abst/-- & $2000-2014$ & Yes & 12 & $\mathbf{1 0}$ \\
\hline $\mathrm{S}_{2}$ & length of stay/stroke/quality of life & Abst/Abst/Abst & $2012-2014$ & Yes & 13 & $\mathbf{7}$ \\
\hline $\mathrm{S}_{3}$ & after stroke/quality of life/length of stay & Abst/Abst/Abst & $2012-2014$ & Yes & 05 \\
\hline $\mathrm{S}_{4}$ & stroke/quality of life/length of stay/functionality & Abst/Abst/Abst/-- & $2012-2014$ & Yes + No & $0+0$ \\
\hline $\mathrm{S}_{5}$ & stroke patients/quality of life/functionality & Abst/Abst/Abst & $2012-2014$ & Yes + No & $0+1$ \\
\hline $\mathrm{S}_{6}$ & stroke/length of stay/functionality & Abst/Abst/Abst & $2012-2014$ & Yes & 0 \\
\hline $\mathrm{S}_{7}$ & stroke/discharge planning/functionality & Abst/Abst/Abst or --- & $2012-2014$ & Yes + No & $0+0$ \\
\hline
\end{tabular}

Note: $S$ - strategy; Abst - abstract; Txt - text; RES - result in number of articles. 
For example, in the first study strategy $\left(\mathrm{S}_{1}\right)$ we used the key words "stroke", "quality of life" and "discharge planning", with the Boolean operator "and" (searched in the "abstract", or without a field definition), and we obtained 12 articles (with a link for full texts) but in a period of 14 years (20002014). Of these 12 articles, 10 were retained, after excluding repeated articles and studies addressing aspects that were not of our interest. Only one article, of 2013, was obtained when we defined the period of 2012-2014 and kept the remaining criteria. A similar reading was conducted with the other strategies $\left(\mathrm{S}_{2} \mathrm{aS}_{7}\right)$.

This methodology, summarized and explained above, resulted in the selection of 18 articles, to which we added another one - a commented article - totaling 19 articles, as illustrated in Figure 1 below. We highlighted the different nature of the studies compiled in terms of type, objectives, and methods, making it difficult to perform the comparison processes and eventual meta-analysis, which was not intended here. The search terms were stroke, quality of life, discharge planning, length of stay, and functionality, in a cross-sectional analysis of Chart 1.

Chart 3 presents the studies selected for this integrative literature review, classified by numerical order, title, publication year and country, method and context where it was conducted and participants involved. The logic of the numerical order is related to the sequence of study strategies adopted.

These studies were analyzed according to the concerns mentioned in the introduction of this study, based on the essential and most relevant aspects of each study.

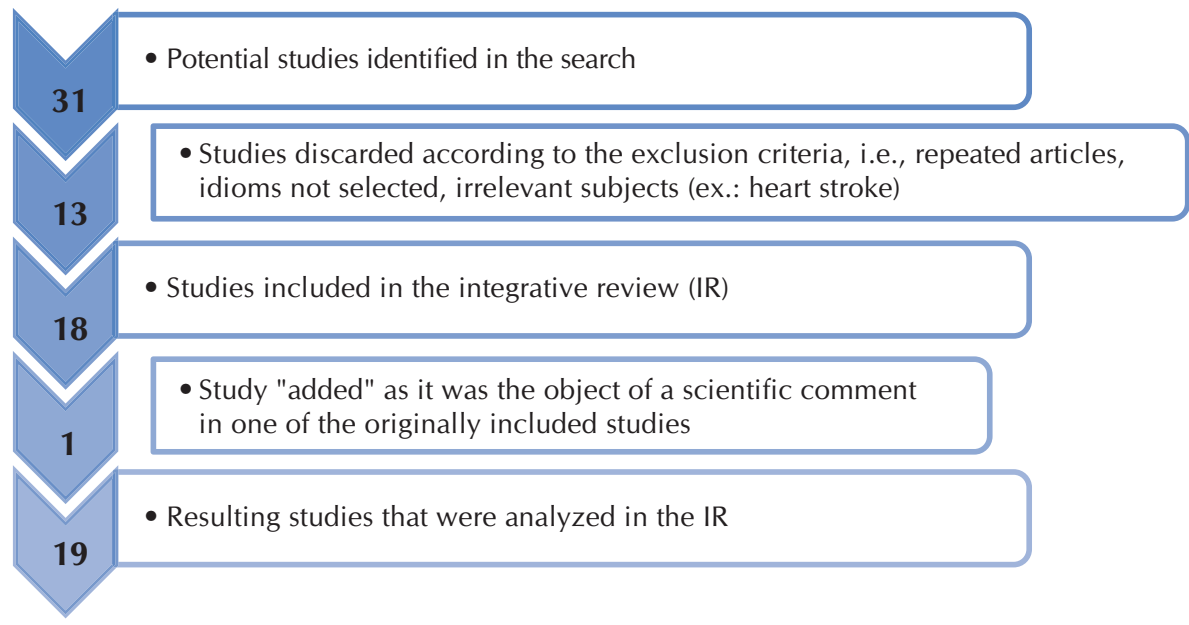

Figure 1 - Diagram illustrating the study selection process for the integrative review

Chart 3 - Distribution of selected articles according to their title, publication year/country, method and context/participants

\begin{tabular}{|c|c|c|c|c|}
\hline $\mathbf{N}^{\circ}$ & Title & $\begin{array}{l}\text { Year/ } \\
\text { country }\end{array}$ & Design/method & Context and participants \\
\hline $\mathrm{E}_{1}^{(7)}$ & $\begin{array}{l}\text { A clinical trial of an individualised } \\
\text { intervention programme for family } \\
\text { caregivers of older stroke victims in Taiwan. }\end{array}$ & $\begin{array}{l}\text { 2010; } \\
\text { Taiwan }\end{array}$ & $\begin{array}{l}\text { Randomized } \\
\text { study }\end{array}$ & $\begin{array}{l}\text { Hospital and homes of patients; elderly patients } \\
\text { with CVA ( } \mathrm{n}=158 ; \mathrm{EG}=72 ; \mathrm{CG}=86 \text { ) and their } \\
\text { family caregivers. }\end{array}$ \\
\hline $\mathrm{E}_{2}^{(8)}$ & $\begin{array}{l}\text { A Randomized Trial Testing the Superiority } \\
\text { of a Postdischarge Care Management } \\
\text { Model for Stroke Survivors. }\end{array}$ & $\begin{array}{l}\text { 2009; } \\
\text { United } \\
\text { States }\end{array}$ & Randomized study & $\begin{array}{l}\text { Hospital/specialized centers and community; } 380 \\
\text { patients }(n=380 ; E G=190 ; C G=190)\end{array}$ \\
\hline $\mathrm{E}_{3}^{(9)}$ & $\begin{array}{l}\text { Discharged after stroke - important factors } \\
\text { for health-related quality of life. }\end{array}$ & $\begin{array}{l}\text { 2010; } \\
\text { Sweden }\end{array}$ & $\begin{array}{l}\text { Cross-sectional } \\
\text { study }\end{array}$ & $\begin{array}{l}\text { Home interviews with patients or in nursing } \\
\text { homes; } 188 \text { patients }(n=188) \text {, consecutively } \\
\text { included. }\end{array}$ \\
\hline $\mathrm{E}_{4}{ }^{(10)}$ & $\begin{array}{l}\text { Early discharge plus home based rehabilitation } \\
\text { reduced length of initial hospital stay but did } \\
\text { not improve health-related quality of life in } \\
\text { patients with acute stroke. }\end{array}$ & $\begin{array}{l}\text { 2000; } \\
\text { United } \\
\text { Kingdom }\end{array}$ & $\begin{array}{l}\text { Comment and } \\
\text { analysis of } \\
\text { scientific articles }\end{array}$ & $\begin{array}{l}\text { Comment and analysis of } 2 \text { scientific articles: } \\
\text { Article } 1 \text { and Article } 2 \text { (S5). }\end{array}$ \\
\hline $\begin{array}{l}\mathrm{E}_{5}^{(11)} \\
{\left[\mathrm{E}_{4.1}\right]}\end{array}$ & $\begin{array}{l}\text { Home or hospital for stroke rehabilitation? } \\
\text { Results of a randomized controlled trial. I: } \\
\text { health outcomes at } 6 \text { months }\end{array}$ & $\begin{array}{c}\text { 2000; } \\
\text { Australia }\end{array}$ & $\begin{array}{l}\text { Randomized } \\
\text { study }\end{array}$ & $\begin{array}{l}\text { Hospital/home of patients/rehabilitation units; } 398 \\
\text { patients with stroke were evaluated. The study } \\
\text { involved } 86 \text { patients }(n=86 ; E G=42 ; C G=44) \text {. }\end{array}$ \\
\hline $\mathrm{E}_{6}{ }^{(12)}$ & $\begin{array}{l}\text { Effectiveness of a postdischarge care } \\
\text { management model for stroke and transient } \\
\text { ischemic attack: a randomized trial. }\end{array}$ & $\begin{array}{l}\text { 2002; } \\
\text { United } \\
\text { States }\end{array}$ & $\begin{array}{l}\text { Randomized } \\
\text { study }\end{array}$ & $\begin{array}{l}\text { Home of patients; } 96 \text { patients with CVATIA* were } \\
\text { included. In the final analysis, } 93 \text { patients }(n=93) \\
\text { were distributed in two groups ( } E G=47 ; C G=46) \text {. }\end{array}$ \\
\hline $\mathrm{E}_{7}^{(13)}$ & $\begin{array}{l}\text { Family conferences in stroke rehabilitation: } \\
\text { a literature review. }\end{array}$ & $\begin{array}{c}\text { 2013; } \\
\text { Australia }\end{array}$ & Literature review & $\begin{array}{l}\text { (n.a./ n.a.); } 23 \text { articles were obtained, } 14 \text { of which } \\
\text { with level of evidence between I and III-3, addressing } \\
\text { with merit the problems presented in this field. }\end{array}$ \\
\hline
\end{tabular}




\begin{tabular}{|c|c|c|c|c|}
\hline $\mathrm{N}^{\circ}$ & Title & $\begin{array}{l}\text { Year/ } \\
\text { country }\end{array}$ & Design/method & Context and participants \\
\hline $\mathrm{E}_{8}^{(14)}$ & $\begin{array}{l}\text { Long-term effects of the intensification } \\
\text { of the transition between inpatient } \\
\text { neurological rehabilitation and home care } \\
\text { of stroke patients. }\end{array}$ & $\begin{array}{l}\text { 2006; } \\
\text { Germany }\end{array}$ & Controlled study & $\begin{array}{l}\text { Hospital; telephone contact and interview, for } 3 \\
\text { years (community/homes). The study involved } 71 \\
\text { patients }(n=71 ; E G=36 ; C G=35)\end{array}$ \\
\hline$E_{9}^{(15)}$ & $\begin{array}{l}\text { Randomized controlled trial of integrated } \\
\text { (managed) care pathway for stroke } \\
\text { rehabilitation. }\end{array}$ & $\begin{array}{l}\text { 2000; } \\
\text { United } \\
\text { Kingdom }\end{array}$ & $\begin{array}{l}\text { Randomized } \\
\text { prospective study }\end{array}$ & $\begin{array}{l}\text { Hospital and community; the study involved } 152 \\
\text { patients }(\mathrm{n}=152 ; \mathrm{EG}=76 ; \mathrm{CG}=76)\end{array}$ \\
\hline $\mathrm{E}_{10}{ }^{(16)}$ & $\begin{array}{l}\text { The trajectory of minor stroke recovery for } \\
\text { men and their female spousal caregivers: } \\
\text { literature review. }\end{array}$ & $\begin{array}{l}\text { 2007; } \\
\text { Canada }\end{array}$ & $\begin{array}{l}\text { Narrative } \\
\text { literature review }\end{array}$ & (n.a./ n.a.); 34 articles were found and included. \\
\hline$E_{11}{ }^{(17)}$ & $\begin{array}{l}\text { Training informal caregivers of patients } \\
\text { with stroke improved patient and caregiver } \\
\text { quality of life and reduced costs. }\end{array}$ & $\begin{array}{l}\text { 2004; } \\
\text { United } \\
\text { Kingdom }\end{array}$ & $\begin{array}{l}\text { Comment and } \\
\text { analysis of } \\
\text { scientific articles }\end{array}$ & $\begin{array}{l}\text { Comment and analysis of one scientific article: } \\
\text { (Enot selected). }\end{array}$ \\
\hline $\mathrm{E}_{12}{ }^{(18)}$ & $\begin{array}{l}\text { Community-applied research of a traditional } \\
\text { Chinese medicine rehabilitation scheme on } \\
\text { Broca's aphasia after stroke: study protocol } \\
\text { for a randomized controlled trial. }\end{array}$ & $\begin{array}{l}2014 ; \\
\text { China }\end{array}$ & $\begin{array}{l}\text { Multi-center, } \\
\text { randomized } \\
\text { study, with blind } \\
\text { evaluation }\end{array}$ & $\begin{array}{l}\text { Hospital and community health centers; the } \\
\text { study involved } 290 \text { patients }(n=290 ; E G=145 ; \\
C G=145)\end{array}$ \\
\hline $\mathrm{E}_{13}{ }^{(19)}$ & $\begin{array}{l}\text { Cost avoidance associated with optimal } \\
\text { stroke care in Canada. }\end{array}$ & $\begin{array}{l}\text { 2012; } \\
\text { Canada }\end{array}$ & $\begin{array}{l}\text { Literature review } \\
\text { / "Evidence from } \\
\text { the literature" }\end{array}$ & (n.a./ n.a.) \\
\hline $\mathrm{E}_{14}{ }^{(20)}$ & $\begin{array}{l}\text { Fabry's disease: A prospective multicenter } \\
\text { cohort study in young adults with } \\
\text { cryptogenic stroke. }\end{array}$ & $\begin{array}{l}\text { 2012; } \\
\text { Canada }\end{array}$ & $\begin{array}{l}\text { Multi-center, } \\
\text { prospective } \\
\text { cohort study } \\
\text { [study protocol] }\end{array}$ & $\begin{array}{l}\text { Hospital and follow-up; all patients* with stroke, } \\
\text { aged } 18 \text { to } 55 \text { years, will be included in the study. } \\
\text { (*At facilities enrolled as participating centers } \\
\text { and working within the broad guidance of the } \\
\text { Canadian Best Practice for Stroke Care). }\end{array}$ \\
\hline $\mathrm{E}_{15}{ }^{(21)}$ & $\begin{array}{l}\text { First-Year Outcomes after Stroke } \\
\text { Rehabilitation: A Multicenter Study in } \\
\text { Thailand. }\end{array}$ & $\begin{array}{l}\text { 2013; } \\
\text { Thailand }\end{array}$ & $\begin{array}{l}\text { Prospective } \\
\text { cohort study }\end{array}$ & $\begin{array}{l}\text { Hospital and follow-up ( } 1 \text { year) after hospital } \\
\text { discharge. Of } 327 \text { patients*, only } 214(65.4 \%) \\
\text { were followed up for at least one year. }\end{array}$ \\
\hline $\mathrm{E}_{16}^{(22)}$ & $\begin{array}{l}\text { Intracerebral hemorrhage and delirium } \\
\text { symptoms. Length of stay, function, and } \\
\text { quality of life in a 114-patient cohort. }\end{array}$ & $\begin{array}{l}\text { 2013; } \\
\text { United } \\
\text { States }\end{array}$ & Prospective study & $\begin{array}{l}\text { Hospital and follow-up; the study involved } 114 \\
\text { patients. }\end{array}$ \\
\hline $\mathrm{E}_{17}^{(23)}$ & $\begin{array}{l}\text { Is it beneficial to increase the provision of } \\
\text { thrombolysis? -- a discrete-event simulation } \\
\text { model. }\end{array}$ & $\begin{array}{l}\text { 2012; } \\
\text { United } \\
\text { Kingdom }\end{array}$ & $\begin{array}{l}\text { Retrospective } \\
\text { study (5 years: } \\
\text { Jan. } 2003 \text { to Dec. } \\
\text { 2007) }\end{array}$ & $\begin{array}{l}\text { Analysis of data extracted from the Patient } \\
\text { Administration System (PAS), of the Belfast City } \\
\text { Hospital (BCH), and transferred from the BCH to the } \\
\text { South-East Belfast Community Stroke Scheme (rehab)]; } \\
\text { in total, } 419 \text { patients were included in the study. }\end{array}$ \\
\hline $\mathrm{E}_{18}{ }^{(24)}$ & $\begin{array}{l}\text { Satisfaction with care as a quality-of-life } \\
\text { predictor for stroke patients and their } \\
\text { caregivers. }\end{array}$ & $\begin{array}{l}\text { 2012; } \\
\text { Netherlands }\end{array}$ & $\begin{array}{l}\text { Cross-sectional } \\
\text { study }\end{array}$ & $\begin{array}{l}\text { Hospital. In total, } 251 \text { dyads (patient and caregiver } \\
\text { couples) were involved in the study. }\end{array}$ \\
\hline $\mathrm{E}_{19}{ }^{(25)}$ & $\begin{array}{l}\text { Depressive symptoms and disability } \\
\text { in chagasic stroke patients: Impact on } \\
\text { functionality and quality of life. }\end{array}$ & $\begin{array}{l}\text { 2013; } \\
\text { Brazil }\end{array}$ & $\begin{array}{l}\text { Cross-sectional } \\
\text { study }\end{array}$ & $\begin{array}{l}\text { Hospital. In total, } 21 \text { patients with Chagas disease } \\
\text { and prior diagnosis of stroke. }\end{array}$ \\
\hline
\end{tabular}

Note: $S$ - study and numerical order (ex.: S18); EG - experimental group; CG - control group; n.a. - not applicable; ${ }^{*} C V A=$ cerebrovascular accident/ TIA = transient ischemic attack.

\section{RESULTS}

Chart 4 shows the main results and conclusions of the studies, presented as central topics or "descriptive aspects". In this summary, the numerical order presented before remains the same, for easy reading, understanding and interpretation of all studies, both individually and collectively. 
Chart 4 - Studies included in the integrative review, highlighting the main results and conclusions

\begin{tabular}{|c|c|}
\hline $\mathbf{N}^{\circ}$ & Results and conclusions: descriptive aspects - summary \\
\hline $\mathrm{S}_{1}\left({ }^{(7)}\right.$ & $\begin{array}{l}\text { In the postdischarge period (12-month follow-up), the caregivers of elderly patients with stroke who participated in the experimental } \\
\text { group provided care of better quality ( } \beta=0.45 ; p=0.03) \text { than those of the control group; between month } 6 \text { and } 12 \text { after discharge, the } \\
\text { probability of re-hospitalization was higher for control group patients than for the experimental group patients }\left(X^{2}=5.11 ; p=0.03\right) \text {. } \\
\text { Conclusion: early attention and care, training, evaluation and follow-up of patients and their families (caregivers) during hospitalization } \\
\text { and after discharge, improve the quality of care provided to patients and reduces re-hospitalization. }\end{array}$ \\
\hline $\mathrm{S}_{2}^{(8)}$ & $\begin{array}{l}\text { Considering all domains analyzed related to stroke [...], the effect size of the treatment was close to } 0[\ldots] \text { for all of them, except } \\
\text { for the domain "knowledge and lifestyle", which showed a significant effect resulting from the intervention }(\mathrm{p}=0.0003) \text {. Only the } \\
\text { domain "knowledge and lifestyle" improved with the intervention, not demonstrating the superiority of any model ("comprehen- } \\
\text { sive postdischarge care management") in relation to others ("organized acute stroke department care with enhanced discharge } \\
\text { planning"). However, in both groups, discharge planning and follow-up were guaranteed. }\end{array}$ \\
\hline $\mathrm{S}_{3}{ }^{(9)}$ & $\begin{array}{l}\text { The depressive symptoms were associated with a lower health-related quality of life (HRQOL). The ability to perform personal and social } \\
\text { activities, the interests, younger age, education (basic, elementary education) and reduced length of stay were associated with higher } \\
\text { HRQoL. The perception of participation in their own discharge planning was positively and negatively associated with HRQLL. } \\
\text { Several variables contribute to HRQoL in two to three weeks after the discharge, particularly fewer depressive symptoms and involve- } \\
\text { ment/participation in social activities (such as outdoor activities and interest-driven activities). } \\
\text { The participation in their own discharge planning was positively and negatively perceived by the patients. }\end{array}$ \\
\hline $\mathrm{S}_{4}^{(10)}$ & $\begin{array}{l}\text { This comment by Griffiths }\left(\mathrm{E}_{4}\right) \text { regarding the study conducted by Anderson et al. }\left(\mathrm{S}_{5}\right) \text { highlights important aspects related to pa- } \\
\text { tients with stroke and the hospital-home transition process (ex.: rehabilitation, length of stay, discharge). } \\
\text { It highlights that early discharge does not lead to significantly better results (at month } 6 \text { ) for the patients and it may cause worse } \\
\text { results in terms of QoL and mental health for their caregivers. It also reminds that the care provided at stroke centers is more effec- } \\
\text { tive than the care provided by general infirmaries. Conclusion: this comment states reduced length of stay (accelerating hospital } \\
\text { discharge) may occur without apparent damage to relatively independent patients with stroke; it also states weak evidence of the } \\
\text { advantages of early discharge and lower costs related to patients (staying) in the (habitual) general care units; it also states further } \\
\text { studies should be conducted on impacts on caregivers [...]. }\end{array}$ \\
\hline $\begin{array}{l}\mathrm{S}_{5}(11) \\
{\left[\mathrm{S}_{4.1}\right]}\end{array}$ & $\begin{array}{l}\text { Study commented by Griffiths }\left[\mathrm{S}_{4}\right] \text {, which presents the following results and conclusions: in general, the clinical results at month } \\
6 \text { after randomization, did not differ significantly in the comparison between the groups, but the total length of stay in the ex- } \\
\text { perimental group was significantly reduced ( } 15 \text { versus } 30 \text { days; } p=0.001) \text {. The caregivers from the "home rehabilitation" group } \\
\text { presented significantly lower levels of mental health (SF-36) [...]. }\end{array}$ \\
\hline $\mathrm{S}_{6}^{(12)}$ & $\begin{array}{l}\text { The groups were analyzed through different approaches: habitual care versus discharge intervention through care planning (interdis- } \\
\text { ciplinary teams) and strict collaboration with primary care units (clinical centers). } \\
\text { A significant improvement was presented in all } 5 \text { domains evaluated (with each domain showing a positive effect of the interven- } \\
\text { tion), leading to a better profile of health and secondary prevention ( } p<0.0001 \text { ), at month } 3 \text { after CVA and after TIA. Thus, this care } \\
\text { management model resulted in significant improvement of the profile of health and secondary prevention at month } 3 \text { after discharge. }\end{array}$ \\
\hline $\mathrm{S}_{7}^{(13)}$ & $\begin{array}{l}\text { The studies/articles suggest that the stroke survivors and their families have additional education and support needs besides the } \\
\text { typical attention, and this intervention may be leveraged by adopting more active (and not reactive) actions, preventing crises or } \\
\text { potentially preventable ruptures. This review provides information about the ideal methods of communication and planning and } \\
\text { identifies how to benefit from these opportunities. Conclusions: there is much to be performed by the multidisciplinary team; } \\
\text { additional investigation and experimental studies [...] will allow improved and better-informed clinical practice and develop bet- } \\
\text { ter practical guidelines to ensure reduced stress and anxiety of caregivers, at admission and discharge; additional investigation is } \\
\text { needed on the effects of education and emotional support provided at hospitals and primary care clinics. }\end{array}$ \\
\hline $\mathrm{S}_{8}^{(14)}$ & $\begin{array}{l}\text { Two and a half years after hospital discharge (t3), significantly fewer patients of the experimental group were hospitalized }(2 \text { versus } 5) \text { or } \\
\text { died ( } 4 \text { versus } 11)[p=0.010] \text {. Participation in an intensive training/work program and hospital discharge process planning leads to better } \\
\text { results in general, even in the long term ( } \mathrm{t} 3 \text { ), representing a significant predictor (the 3rd, related to better functional quality at discharge } \\
\text { and younger age) for lower hospitalization and mortality rates. The effects of participation in a program with these characteristics may } \\
\text { persist in the long term, leading to care maintenance at home and reducing hospitalization and mortality rates. }\end{array}$ \\
\hline $\mathrm{S}_{9}^{(15)}$ & $\begin{array}{l}\text { Despite the numerous results, the study concluded that a well-structured and monitored program, especially in terms of objec- } \\
\text { tives and duration (ICP - Integrated Care Pathway), did not show any advantage over a conventional multidisciplinary approach } \\
\text { (regarding the functional recovery and indicators of quality of life), in patients with stroke followed up at stroke rehabilitation } \\
\text { units. Such indicators of functional recovery and quality of life (QoL) were better and reached more quickly in the group that } \\
\text { received a conventional multidisciplinary approach. }\end{array}$ \\
\hline $\mathrm{S}_{10}{ }^{(16}$ & $\begin{array}{l}\text { The results of this study showed that patients with minor stroke and their spouses and caregivers may experience great challenges } \\
\text { in postdischarge adaptation. Recovery from a minor stroke may require a reformulation of life plans and priorities, and the inclu- } \\
\text { sion of resulting inabilities in current and future situations, for the patients and their spouses and caregivers. In many cases, such } \\
\text { adaptations are aggravated by transitions associated with the normal aging process. } \\
\text { The study concluded that there is not enough information about the recovery process (and the role of caregivers) of patients with } \\
\text { minor stroke in relation to the normal aging process. Therefore, further investigation is required to analyze this transition, to sup- } \\
\text { port discharge planning actions performed by nurses and other health professionals. }\end{array}$ \\
\hline
\end{tabular}

To be continued 


\begin{tabular}{|c|c|}
\hline $\mathbf{N}^{\circ}$ & Results and conclusions: descriptive aspects - summary \\
\hline $\mathrm{S}_{11}{ }^{(17)}$ & $\begin{array}{l}\text { This comment by Stevenson }\left(\mathrm{S}_{11}\right) \text { to the study conducted by Kalra, Evans, Perez et al. }\left(\mathrm{S}_{\text {not selected }}\right) \text { highlights the main results and } \\
\text { conclusions, among other important aspects. This comment provided under the title "Training informal caregivers of patients } \\
\text { with stroke improved patient and caregiver QoL and reduced costs" states that, at month } 12 \text {, the patients from the group of trained } \\
\text { caregivers improved their mood and quality of life, but no difference was observed in relation to the patients from the usual care } \\
\text { group, in terms of mortality, hospitalization and functionality. Regarding the caregivers from the experimental group, they im- } \\
\text { proved their mood and QoL, with reduced overload due to care provision, when compared to the control group of usual care [...]. } \\
\text { In brief, the provision of training to caregivers of patients with stroke improves their QoL and mood/vigor, reduces health care } \\
\text { costs without, however, impacts on mortality, hospitalization and functionality of patients, when compared to usual procedures } \\
\text { of the caregivers without a specific training. }\end{array}$ \\
\hline $\mathrm{S}_{12}^{(18)}$ & $\begin{array}{l}\text { An ongoing experimental study that started in November 2013, and whose last patient was included on August, } 1 \text { st, } 2015 \text {. A } \\
\text { study with acupuncture acting as an experimental variable in the therapeutic process, which comprises speech/language therapy } \\
\text { plus initial therapy (for patients with post-stroke aphasia). }\end{array}$ \\
\hline $\mathrm{S}_{13}{ }^{(19)}$ & $\begin{array}{l}\text { An analysis was conducted (a literature review) of } 4 \text { central aspects in care provision to patients with stroke (fast evaluation and } \\
\text { treatment start; thrombolytic therapy; organized stroke units; early controlled discharge, with community supporting services). } \\
\text { The authors state it would be possible to have substantially better results. They indicate it would be possible to reduce the num- } \\
\text { ber of annual hospital episodes }(3.3 \%) \text {, reduce the number of days in intensive care units }(25.9 \%) \text {, reduce the number of days in } \\
\text { home care }(12.8 \%) \text {, reduce the number of deaths in hospitals }(14.9 \%) \text {, and reduce the amount of direct and indirect costs in the } \\
\text { country. Conclusion: they state that it would be possible to substantially reduce costs and improve clinical results if the effective } \\
\text { and largely known treatment types were more intensively used. }\end{array}$ \\
\hline $\mathrm{S}_{14}{ }^{(20)}$ & $\begin{array}{l}\text { This study addresses the problem of stroke in young people (aged } 18 \text { to } 55 \text { years), relating it to the Fabry disease, in a prospective } \\
\text { study whose objective was to estimate and determine the prevalence of Fabry disease in adult and young patients with stroke. } \\
\text { Conclusion: they assume that this was the first initiative in the country (at the time) developed to determine the prevalence of a } \\
\text { positive result for Fabry disease in young adults with stroke. In addition, this initiative (Canadian Fabry Stroke Screening Initiative) } \\
\text { will provide information about recurrent vascular events, inability present at month } 6 \text { (via modified Rankin scale), and predisposi- } \\
\text { tion of this poorly studied population. }\end{array}$ \\
\hline $\mathrm{S}_{15}{ }^{(21)}$ & $\begin{array}{l}\text { This prospective study without any explicitly defined objectives intended to determine long-term effects of intensive rehabilita- } \\
\text { tion therapy in patients with CVA. In summary, the results indicated low functionality at month } 12 \text { was significantly correlated } \\
\text { with longer length of stay, longer time between stroke and being transferred from acute care to a rehabilitation unit, and higher } \\
\text { levels of depression at month } 12 \text {. Conclusion: about half the patients recovered at least one degree in the level of inability mea- } \\
\text { sured in the follow-up; however, they emphasize that low functionality at month } 12 \text { is associated with longer length of stay (1st } \\
\text { admission), delay in rehabilitation program and psychological depression. }\end{array}$ \\
\hline $\mathrm{S}_{16}^{(22)}$ & $\begin{array}{l}\text { Approach to the prognostic value of delusion symptoms in patients hospitalized in intensive care units (ICUs), with brain injury } \\
\text { caused by intracerebral hemorrhage (not by ischemic stroke). The presence of such symptoms of delusion was associated with } \\
\text { higher probability of negative functional results (poor functionality) and lower QoL in the future, in the domains of cognitive- } \\
\text { executive function, after corrections for brain damage at admission, age, therapeutic measures (benzodiazepines), among others. } \\
\text { Conclusion: they state that, after focal brain injury, the symptoms of delusion are frequent, despite low infection rates and the } \\
\text { sedative therapy, and act as predictors of poor functional results and lower QoL. }\end{array}$ \\
\hline $\mathrm{S}_{17}{ }^{(23)}$ & $\begin{array}{l}\text { A retrospective study that questions and demonstrates how an intensified thrombolytic therapy (thrombolysis) reduces health } \\
\text { care costs (leading to moderate savings) and improves the scores/levels of QoL of patients. Results: the study states the costs (of } \\
\text { thrombolysis) make up for the reduced hospital costs of rehabilitation and hospitalization, with corresponding improvement in } \\
\text { QoL. An increase of } 10 \% \text { to } 50 \% \text { in thrombolytic therapy in eligible patients potentially corresponds to } 8.26 \% \text { savings in (com- } \\
\text { munity) rehabilitation costs and } 12.3 \% \text { savings in hospitalization costs, per patient. }\end{array}$ \\
\hline $\mathrm{S}_{18}{ }^{(24)}$ & $\begin{array}{l}\text { The age of patients was significantly related to their QoL. Also, the age and level of instruction of their caregivers were significant- } \\
\text { ly related to QoL. The inability of patients at hospital admission and length of stay were associated with QoL, and the inability } \\
\text { of patients at hospital admission was also related to the QoL of caregivers. No relation was observed between length of stay and } \\
\text { QoL of caregivers. Patient satisfaction with care provision was associated with the QoL of both patients and caregivers. Using } \\
\text { the APIM model, which can consists in an Actor - Partner (patient - caregiver) Interdependence Model, the authors conclude } \\
\text { that patient satisfaction with care provision was the most important indicator and determinant of QoL of patients and caregivers. }\end{array}$ \\
\hline $\mathrm{S}_{19}{ }^{(25)}$ & $\begin{array}{l}\text { Although the study analyzed a particular group of patients - with stroke and Chagas disease, the authors attempted to investigate } \\
\text { a correlation between inability and depressive symptoms (associated with stroke) with functional performance and QoL. A cor- } \\
\text { relation was observed between the functional scores (mRS and BI), but not with the subscales of QoL; with these subscales, a } \\
\text { correlation was observed between the scores in the depression scale, although depression was not associated with basic func- } \\
\text { tionality. They also observed a stronger correlation and influence on QoL with the depressive symptoms than with the motor } \\
\text { consequences of stroke, although these motor sequelae affect functionality more than the depressive symptoms. }\end{array}$ \\
\hline
\end{tabular}

Note: $S$ - study and its numerical order; $m R S$ - modified Rankin scale; BI - Barthel index; CVA = cerebrovascular accident; HRQoL = Health-related quality of life; $I C U_{S}=$ intensive care units; QoL = quality of life; APIM = Actor - Partner Interdependence Model. 


\section{DISCUSSION}

The selected articles present geographical diversity and use different methodologies (Chart 3), from a simple comment about scientific articles (made by experts) to randomized studies with dual randomization, prospective studies, retrospective studies, cross-sectional studies, literature review and even an ongoing study. Likewise, the number of participants (Chart 2) also presents a high variation, even when not using 'patients' as sample units, but the number of articles in a literature review. Despite such diversity, an effective convergence is observed in the topics addressed, as the authors desired, according to the initial selection of study terms.

Chart 4 provides the main contribution for this discussion, as it presents a summary of the main results and conclusions of each study. Thus, focused on clinical spheres and preparatory, prior or subsequent circumstances (terms used in the search: discharge planning; length of stay; after stroke), we can state, just like $S_{1}{ }^{(7)}$, that the best health care results are obtained with more attention dedicated to the hospital-home transition process, with lower probability of re-hospitalization, despite having no direct impact on the QoL of the patient or caregiver. Moreover, $\mathrm{S}_{2}{ }^{(8)}$ does not present significant differences in the five domains analyzed when comparing two replicable health care models; of these domains, only the one related to knowledge and lifestyle improved with the model, always ensuring discharge planning and follow-up. Another approach used in the studies was the participation of patients in the discharge planning and the relation with a perception of higher or lower HRQoL; $\mathrm{S}_{3}{ }^{(9)}$ shows that such participation can be positively or negatively perceived. In a comment to two studies in this regard, $\mathrm{E}_{4}{ }^{(10)}$ highlights that early discharge does not produce significantly (necessarily) better results for patients, and it may present worse results in terms of quality of life and affect the mental health of caregivers. This important moment of the therapy process (hospital discharge) is also addressed by other studies $\left(\mathrm{S}_{6,8,11}{ }^{(12,14,17)}\right)$, studied or commented in different perspectives, but always aligned with the need to involve all stakeholders, that is, hospital, patient, patient's family, caregivers, healthcare services and patient rehabilitation guarantee. Stroke recovery processes, with increased functionality and QoL, represent multiple transitions of situational and health-disease conditions, where the final process of subjective well-being, well-being in the relationship with others and mastery is relevant ${ }^{(5)}$.

Another aspect to be analyzed and discussed refers to functionality, which may be interpreted in different ways but is unquestionably a dimension usually affected in a patient with stroke. Seven of all 19 studies ( $\sim 37 \%$ ) selected for this review address it explicitly in terms of results and conclusion, although only 3 studies use such functionality as a concept in their objectives.

When associating functionality with the perception of HRQoL, $\mathrm{S}_{3}{ }^{(9)}$ confirms functional, personal/motor and social preservation (among other variables) is related to a better perception of HRQoL, being a significant predictor $\left(\mathrm{S}_{8}{ }^{(14)}\right)$ for lower hospitalization and mortality rates, also in the long term; on the other hand, it seems insensitive to the approaches experimentally used in one study $\left(\mathrm{S}_{9}{ }^{(15)}\right)$, whose objective was to evaluate the effectiveness of a structured program (ICP) in the reduction of length of stay, without affecting such functionality. Other studies/comments agree in these different realities; in $S_{11}{ }^{(17)}$, the provision of training to caregivers of patients with stroke improves important aspects of their own lives but has no impact on the functionality of patients (when compared to usual procedures of caregivers without specific training). In $\mathrm{S}_{16}{ }^{(22)}$, this dimension is correlated to prior focal symptomatology; in $\mathrm{S}_{15}{ }^{(21)}$, there seems to be a relation with a very long length of stay (affecting functionality at month 12), among other aspects related to and resulting from health care as a process.

Another focus is on QoL, which is almost always, or always, affected in patients with stroke or their caregivers. Of the reviewed studies, about $32 \%$ address it in their objectives, assuming it as a focus or measurement of analysis and treatment $\left(\mathrm{S}_{3^{\prime} 10^{\prime} 16^{\prime} 17^{\prime} 18^{\prime} 19^{\prime}}\right)$, but more than half of these studies (10 out of 19) use this dimension to measure results or make comparisons, integrating and analyzing it a result and/or conclusion (refer to the tables presented above).

Although $\mathrm{S}_{1}{ }^{(7)}$ identifies some limitations, it also assumes that, even with several improvements in health care, more training, more attention, evaluation and follow-up, the results did not present better QoL of caregivers or patients. Likewise, $\mathrm{S}_{2}{ }^{(8)}$ and $\mathrm{S}_{9}{ }^{(15)}$ presented similar results in this sense; quality of life did not improve with the application of an intervention when comparing two health care models; and a well-structured and monitored program did not show any advantage over a conventional multidisciplinary approach in terms of improved indicators of QoL.

As addressed before in a reference to $S_{3}{ }^{(9)}$, this study, which evaluates the participation and integration of patients in their own discharge planning, shows some variables (preservation of personal and social functionality, interests, young age, level of education/instruction and shorter length of stay) have a relation with higher HRQoL. Some studies specifically address the sphere of caregivers $\left(\mathrm{S}_{7}{ }^{(13)}, \mathrm{S}_{11}{ }^{(17)}\right)$ or, like $\mathrm{S}_{18}{ }^{(24)}$, address patient-caregiver pairs. One of the conclusions of $S_{7}^{(13)}$ requires "additional investigation about the effects of educational and emotional support on hospital and outpatient clinics, on QoL of caregivers and prevention of re-hospitalization or admission to continuous care units (home care)", while $\mathrm{S}_{11}{ }^{(17)}$ states that, "at month 12, the patients from the group of trained caregivers presented better mood and quality of life" and concludes as follows: "the provision of training to informal caregivers of patients with stroke improves the mood and the QoL of both patients and caregivers," among other equally important aspects. In $\mathrm{S}_{18}{ }^{(24)}$, in brief, "the authors conclude that patient satisfaction with care provision was the most important indicator and determinant of quality of life of patients and caregivers".

Three other studies showed results and conclusions related to this dimension: $S_{16}{ }^{(22)}$ correlates QoL to focal neurological symptomatology (in a particular clinical situation), ensuring that such symptom (delusion) was associated with lower QoL in the future, in the domains of cognitive-executive function; $S_{18}{ }^{(24)}$ shows how an intensified thrombolytic therapy (thrombolysis) produced better scores/levels of quality of life of patients; and $\mathrm{S}_{19}{ }^{(25)}$ correlates this dimension with depressive symptoms rather than with motor consequences (impairment) of stroke. 
Lastly, we analyzed and discussed some of the approaches to depression used by the studies, a dimension perceived and interpreted in the context of psychoemotional manifestations resulting from this neurovascular pathology. It was not used as an objective of studies or search term, but it is often used in studies involving these patients and their family members, particularly in the context of this review. Although only $\mathrm{S}_{19}{ }^{(25)}$ assumes it in its title and/or objectives (depressive symptoms), this manifestation is addressed by $\mathrm{S}_{3}{ }^{(9)}, \mathrm{S}_{15}{ }^{(21)}$ and $\mathrm{S}_{19}{ }^{(25)}$. Depressive symptoms were related to QoL in two cross-sectional studies $\left(\mathrm{S}_{3}{ }^{(9)}, \mathrm{S}_{19}{ }^{(25)}\right)$ and to functionality in a prospective study $\left(\mathrm{S}_{15}{ }^{(21)}\right)$, exploring its interactions, often with losses (lower QoL and lower functionality) due to the manifestations or levels of the depressive symptoms evaluated.

\section{FINAL CONSIDERATIONS}

A healthy brain involves the idea of a complex global mechanism and a mystery in constant revelation ${ }^{(26-31)}$; many of the effects of brain injury and pathology are likewise diversified, complex and present high interindividual variability ${ }^{(32)}$.

As discussed above and presented in the tables of this review, there is no single sense that could be applied to all realities and all patients. It may even contradict some of the results and topics presented in this study, in particular those related to QoL; however, we emphasize an idea discussed above: "patient satisfaction with care provision was the most important indicator and determinant of QoL of patients and caregivers".
After a more comprehensive reading of these studies, the relation between a functional-physical and psychoemotional (depression) dimension and QoL perceived seems clearly intricate; we have not evaluated specifically this psychoemotional dimension, but it was referred to and correlated in several studies, as indicated above. Contradicting possible "technicist" trends in the current care provision, this reference to "satisfaction with care provision", eventually based on a relational dimension, should be highlighted for the definition of a good health system, for patient-centered supporting services, patients in transition, or in the sphere of education, particularly in nursing training programs.

In summary, given the study question and objectives defined for this integrative review, we can conclude that length of stay and, particularly, a careful, timely and personalized discharge planning tend to have an impact on the QoL of patients (and their caregivers) and on their functionality, understood in lato sensu, when analyzing references to the persistence of psychoemotional alterations extending over a long time and constituting a characteristic and a potential alert to the need for a therapeutic intervention. This transition is critical in a complex physical and psychological process of adaptation to a different condition.

\section{ACKNOWLEDGMENT}

The authors would like to thank the institution to which they are affiliated: ESEnfC - Escola Superior de Enfermagem, in Coimbra, Portugal, for the support to conduct this study under an ongoing project and for the resources assigned to its publication.

\section{REFERENCES}

1. Silva S, Gouveia M. Program “Via verde do AVC": analysis of the impact on stroke mortality. Rev Port Saude Pub. 2012;30(2):172-9.

2. Almeida ADL. A eficácia do proFamílias em doentes de Acidente Vascular Cerebral (AVC) e cancro e seus familiares. Rev Port Saude Pub. 2011;29(1):47-52.

3. NewsFarma. DGS apresenta resultados do relatório “Hipertensão Arterial nos Cuidados de Saúde Primários"[Internet]. 2015 [cited 2016 May 10]. Available from http://www.newsfarma.pt/noticias?start $=15$

4. O'Donnell MJ, Xavier D, Liu L, Zhang H, Chin SL, Rao-Melacini P, et al. Risk factors for ischaemic and intracerebral haemorrhagic stroke in 22 countries (the INTERSTROKE study): a case-control study. Lancet[Internet]. 2010[cited 2016 May 10];376(9735):11223. Available from: http://www.thelancet.com/journals/lancet/article/PIIS0140-6736(10)60834-3/abstract

5. Meleis Al. Transitions theory: middle-range and situation-specific theories in nursing research and practice. New York: Springer; 2010. 641 p.

6. Morin E. Introdução ao Pensamento Complexo. 5a ed. Lisboa, Portugal: Instituto Piaget; 2008. 178 p.

7. Shyu Y-IL, Kuo L-M, Chen M-C, Chen S-T. A clinical trial of an individualised intervention programme for family caregivers of older stroke victims in Taiwan. J Clin Nurs[Internet]. 2010[cited 2016 May 10];19(11-12):1675-85. Available from: http://onlinelibrary.wiley.com/doi/10.11 11/j.1365-2702.2009.03124.x/abstract

8. Allen K, Hazelett S, Jarjoura D, Hua K, Wright K, Weinhardt J, et al. A randomized trial testing the superiority of a post-discharge care management model for stroke survivors. J Stroke Cerebrovasc Dis[Internet]. 2009[cited 2016 May 10];18(6):443-52. Available from: https:// www.ncbi.nlm.nih.gov/pmc/articles/PMC2802837/pdf/nihms-161670.pdf

9. Almborg A-H, Ulander K, Thulin A, Berg S. Discharged after stroke: important factors for health-related quality of life. J Clin Nurs[Internet]. 2010[cited 2016 May 10];19(15-16):2196-206. Available from: http://onlinelibrary.wiley.com/doi/10.1111/j.1365-2702.2010.03251.x/ abstract

10. Griffiths P. Early discharge plus home based rehabilitation reduced length of initial hospital stay but did not improve health related quality of life in patients with acute stroke. Evid Based Nurs. 2000;3(4):2. 
11. Anderson C, Rubenach S, Mhurchu CN, Clark M, Spencer C, Winsor A. Home or hospital for stroke rehabilitation? results of a randomized controlled trial - I: Health outcomes at 6 months. Stroke. 2000;31(5):1024-31.

12. Allen KR, Hazelett S, Jarjoura D, Wickstrom GC, Hua K, Weinhardt J, et al. Effectiveness of a postdischarge care management model for stroke and transient ischemic attack: a randomized trial. J Stroke Cerebrovasc Dis[Internet]. 2002[cited 2016 May 10];11(2):88-98. Available from: http://www.strokejournal.org/article/S1052-3057(02)00019-8/abstract

13. Loupis YM, Faux SG. Family Conferences in Stroke Rehabilitation: a literature review. J Stroke Cerebrovasc Dis[Internet]. 2013[cited 2016 Jul 10];22(6):883-93. Available from: http://www.strokejournal.org/article/S1052-3057(12)00408-9/abstract

14. Graesel E, Schmidt R, Biehler J, Schupp W. Long-term effects of the intensification of the transition between inpatient neurological rehabilitation and home care of stroke patients. Clin Rehabil. 2006;20(7):577-83.

15. Sulch D, Perez I, Melbourn A, Kalra L. Randomized controlled trial of integrated (managed) care pathway for stroke rehabilitation. Stroke. 2000;31(8):1929-34.

16. Green TL, King KM. The trajectory of minor stroke recovery for men and their female spousal caregivers: literature review. J Adv Nurs[Internet]. 2007[cited 2016 May 10];58(6):517-31. Available from: http://onlinelibrary.wiley.com/doi/10.1111/j.1365-2648.2007.04321.x/abstract

17. Stevenson D. Training informal caregivers of patients with stroke improved patient and caregiver quality of life and reduced costs. Evid Based Nurs[Internet]. 2004[cited 2016 May 10];7(4):118. Available from: http://ebn.bmj.com/content/7/4/118.long

18. Tao J, Fang Y, Wu Z, Rao T, Su Y, Lin L, et al. Community-applied research of a traditional Chinese medicine rehabilitation scheme on Broca's aphasia after stroke: study protocol for a randomized controlled trial. Trials[Internet]. 2014[cited 2016 May 10];15. Available from: https://www.ncbi.nlm.nih.gov/pmc/articles/PMC4223562/

19. Krueger H, Lindsay P, Cote R, Kapral MK, Kaczorowski J, Hill MD. Cost avoidance associated with optimal stroke care in Canada. Stroke[Internet]. 2012[cited 2016 May 10];43(8):2198-U366. Available from: http://stroke.ahajournals.org/content/43/8/2198.long

20. SaposnikG,LanthierS,MamdaniM,ThorpeKE,MeloM,PopeK,etal.Fabry'sdisease:aprospectivemulticentercohortstudyinyoungadultswith cryptogenic stroke. Int J Stroke[Internet]. 2012[cited 2016 May 10];7(3):265-73. Available from: http://journals.sagepub.com/doi/pdf/10.11 11/j.1747-4949.2011.00734.x

21. Kuptniratsaikul V, Kovindha A, Piravej K, Dajpratham P. First-Year Outcomes after Stroke Rehabilitation: a multicenter study in Thailand. ISRN Rehabil[Internet]. 2013[cited 2016 May 10];2013 (ID 595318):[6 pages]. Available from: https://www.hindawi.com/journals/ isrn/2013/595318/

22. Naidech AM, Beaumont JL, Rosenberg NF, Maas MB, Kosteva AR, Ault ML, et al. Intracerebral hemorrhage and delirium symptoms length of stay, function, and quality of life in a 114-patient cohort. Am J Resp Crit Care Med[Internet]. 2013 [cited 2016 May 10];188(11):1331-7. Available from: https://www.ncbi.nlm.nih.gov/pmc/articles/PMC3919076/pdf/rccm.201307-1256OC.pdf

23. Barton M, McClean S, Gillespie J, Garg L, Wilson D, Fullerton K. Is it beneficial to increase the provision of thrombolysis? a discrete-event simulation model. Qjm-an Intern J Med[Internet]. 2012[cited 2016 May 10];105(7):665-73. Available from: http://qjmed.oxfordjournals.org/ content/105/7/665.long

24. Cramm JM, Strating MMH, Nieboer AP. Satisfaction with care as a quality-of-life predictor for stroke patients and their caregivers. Qual Life Res[Internet]. 2012[cited 2016 May 10];21(10):1719-25. Available from: https://www.ncbi.nlm.nih.gov/pmc/articles/PMC3496478/ pdf/11136_2011_Article_107.pdf

25. Souza ACd, Rocha MOdC, Teixeira AL, Dias Junior JO, Sousa LAPd, Nunes MCP. Depressive symptoms and disability in chagasic stroke patients: impact on functionality and quality of life. J Neurol Sci[Internet]. 2013[cited 2016 May 10];324(1-2):34-7. Available from: http://www.jns-journal.com/article/S0022-510X(12)00525-4/abstract

26. Nunes HJM, Queirós PJP. Exploratory study of patients' life situation after a stroke. International J Caring Sci[Internet]. 2015[cited 2016 May 10];8(1):101-7. Available from: http://www.internationaljournalofcaringsciences.org/docs/12-Nunes-Original.pdf

27. Damásio AR. Descartes error and the future of human life. Scientific Am. 1994;271(4):144.

28. Pires JC. De Profundis, Valsa Lenta. $4^{\text {a }}$ ed. Lisboa: Dom Quixote; 1997. 69 p.

29. Damásio AR. Descartes' error revisited. J Hist Neuroscienc. 2001;10(2):192-4.

30. Sacks O. O Homem que Confundiu a Mulher com um Chapéu e outros contos clínicos. Lisboa: Relógio D’Água; 1990.256 p.

31. Damásio A. O Livro da Consciência: a construção do cérebro consciente. Lisboa: Temas e Debates; 2010. 437 p.

32. Moreira RP, Araújo TL, Cavalcante TF, Guedes NG, Lopes MVO, Chaves ES. [Concept analysis of the nursing outcome mobility in patients with stroke]. Rev Bras Enferm[Internet]. 2014[cited 2016 May 10];67(3):443-59. Available from: www.scielo.br/pdf/reben/ v67n3/0034-7167-reben-67-03-0443.pdf Portuguese. 